\title{
PENGENALAN MOTIF BATIK BANYUWANGI BERDASARKAN FITUR GRAY LEVEL CO-OCCURRENCE MATRIX
}

\author{
Lutfi Hakim ${ }^{1)}$, Sepyan Purnama Kristanto ${ }^{2)}$, Dianni Yusuf ${ }^{3)}$, Fitri Nur Afia ${ }^{2)}$ \\ ${ }^{1,2,3,4}$ Teknik Informatika, Politeknik Negeri Banyuwangi \\ ${ }^{1,2,3,4} \mathrm{Jl}$. Raya Labanasem KM. 13, Banyuwangi, 68461 \\ Email: ${ }^{1} l u t f i @ p o l i w a n g i . a c . i d,{ }^{2}$ sepyan@poliwangi.ac.id, ${ }^{3}$ dianniyusuf@poliwangi.ac.id, \\ fitrinurafia@gmail.com
}

\begin{abstract}
Batik is one of Indonesia's cultural heritages that is recognized around the world and has existed since the colonial era. Indonesia has a variety of different batik pattern in every Indonesia's region. It causes many ordinary people and tourists to become harder to identify and recognize the existing patterns. Banyuwangi regency itself has more than 10 batik patterns, including the Gajah Oling pattern which in the oldest batik pattern. For preserving the culture and supporting the growing tourism aspect in Banyuwangi, this study developed a system for recognizing Banyuwangi batik patterns based on digital image processing. This system is built using python language and is able to recognize three classes of Banyuwangi batik patterns, such as Gajah Oling, Kopi Pecah and other Banyuwangi batik patterns. This system proposes Gray Level Co-occurrence Matrix (GLCM) as feature extraction method and k-Nearest Neighbors (kNN) as classification method. Based on the experiments that have been carried out, the optimal accuracy is $87,5 \%$ with the K parameter of $k N N$ is 9 .
\end{abstract}

Keywords: Gajah Oling pattern, Kopi Pecah pattern, Batik Classification, digital image processing, kNN

\begin{abstract}
Abstrak
Batik merupakan salah satu warisan budaya Indonesia yang diakui dunia dan telah ada sejak jaman penjajahan. Indonesia memiliki beragam motif batik yang berbeda setiap daerah, sehingga menyebabkan banyak masyarakat awam dan wisatawan sulit membedakan dan mengenali motif-motif yang ada. Kabupaten Banyuwangi sendiri memiliki lebih dari 10 motif batik, diantara adalah motif batik motif gajah oling yang merupakan motif batik tertua. Untuk menjaga kelestarian budaya dan mendukung aspek pariwisata di Banyuwangi yang semakin berkembang, penelitian ini melakukan pengembangan sistem pengenalan motif batik Banyuwangi berbasiskan pengolahan citra digital. Sistem ini dibangun menggunakan bahasa python dan mampu mengenali tiga kelas motif batik Banyuwangi, seperti motif batik Gajah Oling, Kopi Pecah dan motif batik selain keduanya. Proses pengenalan mengusulkan metode ekstraksi fitur Gray Level Cooccurrence Matrix (GLCM) dan metode klasifikasi k-Nearest Neighbors (k-NN). Berdasarkan eksperimen yang telah dilakukan didapatkan akurasi optimal sebesar 87,5\% dengan parameter $\mathrm{K}$ dari algorima kNN adalah 9 .
\end{abstract}

Kata Kunci: Batik Gajah Oling, Motif batik Kopi Pecah, klasifikasi batik, pengolahan citra digital, kNN

\section{Pendahuluan}

Batik adalah salah satu karya anak bangsa Indonesia yang merupakan perpaduan antara unsur seni dan teknologi. Batik menjadi salah satu warisan terbaik dari leluhur bangsa Indonesia dan dapat berkembang hingga sampai pada suatu tingkatan yang tak ada bandinganya baik dalam desain, motif maupun prosesnya. Corak ragam batik yang mengandung penuh makna dan filosofi akan terus digali dari berbagai adat istiadat maupun budaya yang berkembang di Indonesia. Di berbagai daerah, setiap motif batik memiliki unsur kekhasan berdasarkan karakteristik daerah, sejarah dan filosofi daerah itu sendiri, tak terkecuali motif batik-batik Banyuwangi. Batik pesisiran adalah istilah yang diberikan pada produk-produk batik di luar dinding keraton. Batik pesisiran Banyuwangi mempunyai kekhasan tersendiri dibandingkan dengan batik dari daerah lain. Para pencipta motif batik pada zaman dahulu tidak sekedar mencipta sesuatu yang hanya indah dipandang mata saja, tetapi mereka juga memberi makna atau arti yang erat hubungannya dengan filsafat hidup yang mereka hayati. Salah satunya kekhasan batik Gajah Oling yang terletak pada motif yang banyak mengambil motif flora dan fauna sebagai unsur alam [1].

Peningkatan pariwisata di Banyuwangi semakin pesat dan tingkat kreatifitas pengerajin batik juga berkembang, sehingga banyak pengerajin yang berlombalomba menciptakan motif-motif baru baik dengan motif yang relatif baru maupun dengan kombinasi dari beberapa motif. Masyarakat Banyuwangi sendiri seringkali sulit membedakan dan mengenali motif-motif batik yang baru di Banyuwangi dan hingga saat ini belum ada sistem yang 
dapat mengenali atau mengidentifikasi motif batik Banyuwangi. Selain itu, informasi terkait makna dan filosofinya banyak sekali yang belum mengetahuinya sehingga hal ini menjadi kendala tersendiri terkait dengan kepercayaan diri masyarakat terkait untuk mengenalkan warisan budaya kepada masyarakat luas dan khususnya terhadap wisatawan mancanegara. Hal ini akan kurang efektif dalam menjaga kelestarian budaya daerah yang tentunya menjadi identitas dari daerah itu sendiri terhadap kekayaan budaya yang dimiliki.

Beberapa penelitian telah dilakukan untuk mengatasi hal tersebut dimana salah satunya adalah mengembangkan sistem yang dapat mengenali atau mengidentifikasi motif batik berbasiskan pengolahan citra digital, seperti yang dilakukan oleh Agastya dkk dan Khasanah dkk yang mengimplementasikan data augmentasi dan algoritma deep learning untuk mengklasifikasikan motif batik Ceplok, Kawung, Lereng, Nitik dan Parang [2], [3]. Dengan metode yang diusulkan Agastya dkk, mampu mendeteksi kelima motif batik tersebut dengan akurasi mencari 90\%. Sedangkan metode usulan Khasanah dkk. mampu mencapai akurasi yang lebih tinggi dengan persentase optimal sebesar $98,96 \%$ dengan jumlah dataset 500 citra dan menggunakan 8 data augmentasi. Selain itu, Bariyah dkk juga mengimplementasikan algoritma Deep Learning yang spesifik pada penggunaan algoritma Convolutional Neural Network [4]. Mereka melakukan klasifikasi multi-label pada 15 motif batik diantaranya motif Banji, Semen, Kawung, Ceplok, Parang, Buketan, Encim, Sekar Jagad, Truntum, Lung-lungan, Madura, Parang Rusak, Mega Mendung, Kipas dan Fauna. Dalam metodologi yang diusulkan, output yang dihasilkan dapat mendeteksi lebih dari satu motif batik dalam satu citra. Akurasi dari algoritma yang diusulkan mencapai 91,41\% dari 300 citra uji dengan menggunakan epoch 100 . Penelitian lain dilakukan oleh Hardiyanto dkk yang melakukan klasifikasi dua motif batik Yogyakarta yakni motif Parang Kusumo dan Kawung [5]. Mereka menggunakan metode Adaptive Neuro Fuzzy Inference System untuk melakukan klasifikasi kedua motif batik tersebut dan mendapatkan akurasi deteksi yang paling optimal sebesar $80 \%$. Selain itu, Aditya dkk menggunakan metode ekstraksi fitur Gray Level Co-Occurrence Matrix (GLCM) dan statistical color $R G B$ untuk melakukan klasifikasi motif batik lereng, parang, nitik, lung-lungan, semen dan buketan dan metode usulan dapat mengklasifikasi motif batik tersebut dengan akurasi mencapai 94\%.

Berdasarkan penelitian yang telah dilakukan, hampir sebagian besar melakukan klasifikasi motif batik luar Banyuwangi. Padahal di Banyuwangi sendiri memiliki banyak motif yang tersedia. Amal dkk. menyebutkan terdapat 12 motif [6]. Pada perkembangannya, hingga saat ini ada lebih dari 20 motif batik asli Banyuwangi. Oleh karena itu, untuk menjaga kelestarian budaya, penelitian ini melakukan kajian terkait dengan klasifikasi motif batik Banyuwangi berbasiskan citra. Harapannya dengan sistem yang dikembangkan dapat membantu menjaga kelestarian pariwisata dan budaya Banyuwangi. Berdasarkan eksperimen yang telah dilakukan, masih terkumpulkan beberapa jenis motif batik Banyuwangi seperti motif Gajah Oling, Kopi pecah dan beberapa motif lain dengan jumlah yang terbatas. Oleh karena itu, pada penelitian ini mencoba melakukan studi dengan melakukan pengenalan motif batik tersebut berbasis pengolahan citra dengan mengusulkan metode ekstraksi fitur GLCM dan $k$-Nearest Neighbors (kNN) sebagai algoritma klasifikasi. Proses klasifikasi dilakukan berdasarkan tiga kelas output, yakni kelas motif batik Gajah Oling, motif batik kopi pecah dan kelas selain kedua motif batik tersebut.

\section{Metode Penelitian}

Proses pengambilan data dilakukan di salah satu pengrajin batik Banyuwangi dimana tepatnya di Desa Blimbingsari, Kecamatan Rogojampi, Kabupaten Banyuwangi, Jawa Timur. Data motif batik yang diambil adalah citra motif batik gajah oling, kopi pecah, dan selain motif keduanya yang diambil secara acak sesuai dengan stok yang ada pada pengrajin. Ketiga jenis motif batik ini dijadikan output dari deteksi batik yang diusulkan pada penelitian ini. Untuk sampel dataset motif batik yang digunakan dalam penelitian ini ditunjukkan pada gambar 1 berikut.

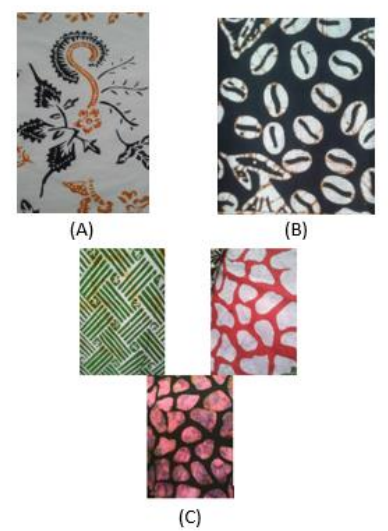

Gambar 1. (A) Gajah Oling,(B) Kopi Pecah, (C) Motif batik lain

Proses deteksi motif batik berbasis citra memuat beberapa Langkah, antara lain proses akuisisi citra, pra-proses, tahap klasifikasi (pencocokan), dan tahap evaluasi performasi sistem. Flow proses deteksi ini ditunjukkan pada gambar 2 berikut:

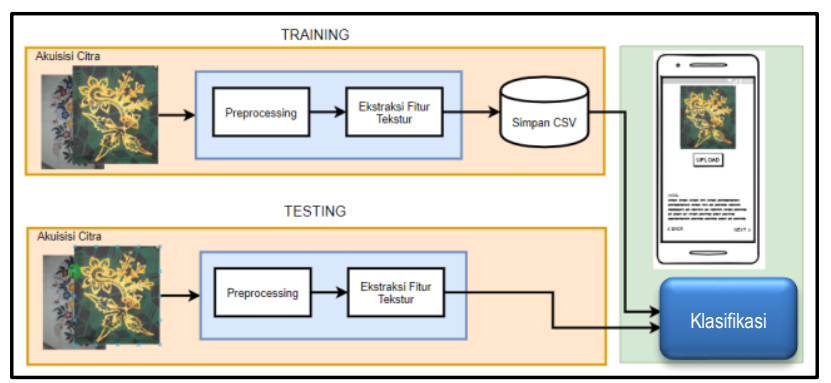

Gambar 2. Flow proses deteksi 


\subsection{Akuisisi Citra}

Tahap akuisisi citra merupakan tahap awal dari penelitian ini yang meliputi persiapan alat yang digunakan sampai dengan pengambilan dataset yang akan digunakan. Tahapan akuisisi citra menggunakan kamera smartphone tanpa melalui proses perbaikan citra atau image restoration. Hasil akuisisi citra ini didapatkan dataset dengan ukuran resolusi gambar sebesar $2560 \times 1440$ piksel dengan resolusi kamera sebesar 5 MP. Proses pengambilan dataset dilakukan pada siang hari dan di dalam ruangan dengan jarak pengambilan yang sama dari setiap dataset yang diambil yakni $50 \mathrm{~cm}$.

\subsection{Pre-processing}

Tahap pre-processing merupakan tahap lanjutan setelah tahap akuisisi citra. Pada tahapan ini melakukan transformasi dari citra asli yang memiliki ruang warna RGB (Red, Green, dan Blue) menjadi citra keabuan (grayscale). Persamaan yang digunakan untuk mendapatkan nilai derajat keabuan ditunjukkan pada persamaan 1 berikut dimana nilai $\mathrm{R}$ adalah nilai warna merah, $G$ adalah nilai warna hijau dan $B$ adalah nilai warna biru dari setiap piksel dari dataset.

$$
\text { Grayscale }=\frac{\mathrm{R}+\mathrm{G}+\mathrm{B}}{3}
$$

\subsection{Ekstrasi Fitur}

Proses ekstraksi fitur adalah proses pencarian ciri agar sistem dapat mengenali karakteristik unik dari masingmasing motif batik yang diwujudkan dalam metode pengolahan citra. Metode Gray Level Co-occurerncce matrix atau GLCM merupakan metode yang digunakan pada penelitian ini. Metode ini merupakan matriks yang merepresentasikan hubungan ketetanggan antar piksel dalam citra pada berbagai arah orientasi (sudut $\boldsymbol{\theta}$ ) dan jarak spasial (d) [7]. Metode GLCM terdiri dari beberapa metode dan pada penelitian ini menggunakan lima metode yang dijadikan sebagai fitur usulan, diantaranya:

1. Kontras (contrast) adalah distribusi piksel terang dan gelap dari sebuah citra. Batas nilai kontras dari 0 hingga pangkat 2. Nilai kontras didapatkan dengan persamaan berikut:

$$
\text { Kontras }=\sum_{i=1}^{L} \sum_{j=1}^{L}(1-2)^{2} \operatorname{GLCM}(i, j)
$$

2. Dissimilarity adalah persamaan yang mengukur ketidakmiripan pada suatu tekstur dimana nilai ini akan bernilai besar apabila bentuk tekstur acak dan bernilai kecil jika bentuk tekstur seragam. Untuk menghitung nilai dissimilarity didapatkan dengan menggunakan persamaan berikut:

$$
\text { Dissimilarity }=\sum_{i=1}^{L} \sum_{j=1}^{L}|i-j| \operatorname{GLCM}(i, j)(3)
$$

3. Homogenitas (Homogenity) adalah representasi dari ukuran nilai kesamaan variasi dari intensitas citra. Apabila semua nilai piksel memiliki nilai yang seragam maka homogenitas memiliki nilai maksimum. Persamaan untuk menghitung nilai homogenitas adalah sebagai berikut:

Homogenitas $=\sum_{i=1}^{L} \sum_{j=1}^{L} \frac{G L C M(i, j)}{1+(i-j)^{2}}$

4. Energy (ASM) adalah penjumlahan yang berkaitan dengan keberagaman intensitas keabuan dalam piksel. Persamaan untuk mendapatkan nilai energy adalah sebagai berikut:

$$
\operatorname{ASM}=\sum_{i=1}^{L} \sum_{j=1}^{L}(\operatorname{GLCM}(i, j))^{2}
$$

5. Korelasi (Correlation) adalah perhitungan yang memiliki keterkaitan linier pada derajat citra keabuan. Kisaran nilai korelasi adalah dari -1 hingga 1. Untuk mendapatkan nilai korelasi dengan menggunakan persamaan berikut:

$$
\text { Korelasi }=\sum_{i=1}^{L} \sum_{j=1}^{L} \frac{\left(i-\mu_{i^{\prime}}\right) *\left(i-\mu_{j^{\prime}}\right)^{*} \operatorname{GLCM}(i, j)}{\sigma_{i^{\prime}} * \sigma_{j^{\prime}}}(6)
$$

Proses ekstraksi fitur ini menghasilkan lima ciri atau fitur usulan yang disimpan dalam file berformat csv. Proses ini dilakukan pada semua dataset yang dikumpulkan yang terdiri dari tiga kelompok atau kelas motif batik, yaitu motif batik Gajah Oling, Kopi Pecah dan motif batik lain. Hasil ekstraksi fitur yang tersimpan dalam file berformat csv tersebut merupakan data acuan yang lebih dikenal dengan data latih.

\subsection{Klasifikasi}

Tahap klasifikasi adalah tahapan pencocokan antara data tes (testing data) dan data latih (training data). Data tes merupakan data baru selain yang digunakan pada data latih. Untuk melakukan klasifikasi, data tes baru juga melewati tahapan yang sama dengan tahap mendapatkan data latih yakni dari akuisisi citra hingga ekstraksi fitur, sehingga fitur yang didapatkan dari data latih dicocokan dengan data latih. Proses pencocokan ini adalah tahap klasifikasi yang mana pada tahapan ini menggunakan metode k-Nearest Neighbors. Metode ini bekerja berdasarkan jarak terpendek dari query instance ke training sample untuk menentukan kNN. Training sample diproyeksikan ke ruang dimensi banyak dimana masingmasing dimensi merepresentasikan fitur dari data [8].

Pada algoritma $\mathrm{kNN}$, tahap pertama yang dilakukan adalah menentukan $\mathrm{K}$ tetangga. Penentuan $\mathrm{K}$ ini sangat mempengaruhi hasil performansi dari klasifikasi. Setelah itu, mencari jarak terdekat antara data tes dan data latih. Ada banyak rumus jarak yang digunakan dalam algoritma kNN. Pada penelitian ini menggunakan rumus jarak Euclidean dalam mencari jarak terdekat karena berdasarkan beberapa literatur menyebutkan rumus jarak ini paling powerful dibandingkan dengan rumus jarak lainnya [9]-[12]. Rumus jarak Euclidean didapatkan dengan menggunakan persamaan berikut:

$$
d_{i}=\sqrt{\sum_{k}^{p}=\left(x_{2 i-} x_{2 i}\right)^{2}}
$$




\subsection{Evaluasi Performasi Sistem}

Tahap ini merupakan tahap pengujian sistem untuk mengukur seberapa akurat metode usulan mengenali motif batik. Penelitian ini menggunakan nilai akurasi untuk mengukur performansi sistem dengan persamaan sebagai berikut.

$$
\text { akurasi }=\frac{\text { data yang benar }}{\text { jumlah data } u j i} \times 100
$$

Dimana nilai akurasi didapatkan dari pembagian antara data yang benar dan jumlah semua data yang diuji. Nilai 100 menunjukkan persentase dari akurasi sistem

\section{Hasil dan Pembahasan}

\subsection{Hasil dari Pengambilan Dataset}

Tahap pengambilan dataset mendapatkan 79 citra dari motif batik Gajah Oling, 89 citra dari motif Kopi pecah serta 48 citra selain dari kedua motif tersebut, sehingga total dataset yang didapatkan sejumlah 216 citra. Berikut merupakan sampel dari dataset yang digunakan.

Tabel 1. Hasil pengambilan dataset

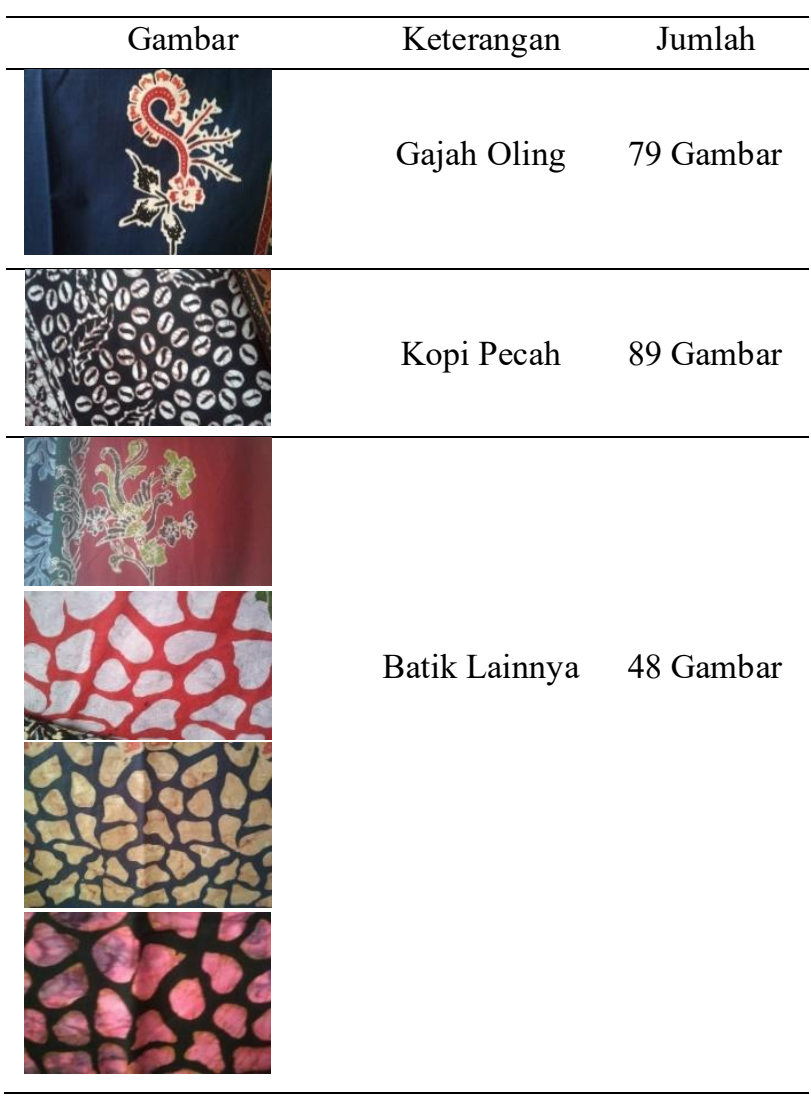

\subsection{Hasil Tahap Pre-Processing}

Tahap pre-processing dilakukan proses transformasi dari citra asli yang memiliki ruang warna RGB menjadi citra keabuan (greyscale). Hasil dari proses ini ditunjukkan pada tabel berikut:
Tabel 2. Hasil Pre-processing

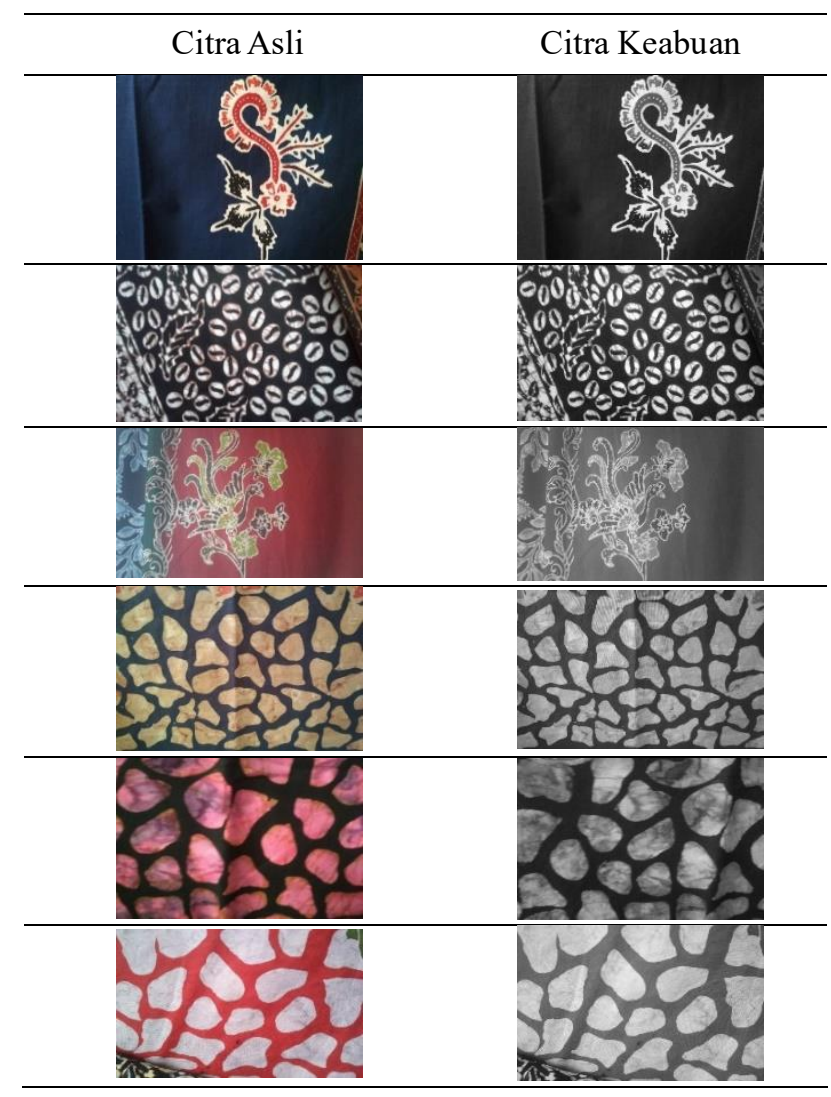

\subsection{Hasil Tahap Ekstraksi Fitur}

Tahap ekstraksi fitur merupakan salah satu tahapan yang sangat penting karena pada tahap ini yang menentukan ciri unik dari masing-masing motif batik. Jika metode yang dipilih tidak sesuai dengan karakteristik pengenalan objek, maka akan sangat berpengaruh terhadap performansi sistemnya. Pada tahapan ekstraksi fitur terdapat tahapan pembuatan matrix co-occurrence, dalam proses pembuatan matrix ini meliputi beberapa langkah, seperti: 1) Mencari jumlah hubungan spasial pada matrix grayscale, 2) Selanjutnya matrix co-occurrence di transpose untuk mengubah baris menjadi kolom, 3) Kemudia dilanjutkan dengan pembuatan matrix simetris dengan cara menjumlahkan matrix co-occurrence dengan matrix transpose, 4) Selanjutnya matrix simestris dinormalisasikan nilai-nilainya dengan membaginya dengan jumlah total kemungkinan (jumlah nilai piksel), dan 5) Langkah selanjutnya yaitu mengekstraksi informasi statistiknya ke dalam beberapa fitur yakni diantaranya adalah nilai kontras, dissimilarity, homogenitas, energy dan korelasi.

Proses untuk mencari nilai dari fitur-fitur tersebut menggunakan library skimage dimana dalam 216 data training dibutuhkan waktu selama kurang lebih 1 menit 7 detik untuk mendapatkan nilai setiap fitur. Penggunaan teknik ini sangat efektif digunakan dalam proses ekstraksi fitur karena beberapa penelitian terdahulu dengan objek penelitian yang berbeda mendapatkan akurasi yang cukup tinggi [13]-[17]. Hasil ekstraksi fitur pada batik gajah oling, kopi pecah dan batik lainnya ditunjukkan pada gambar berikut: 


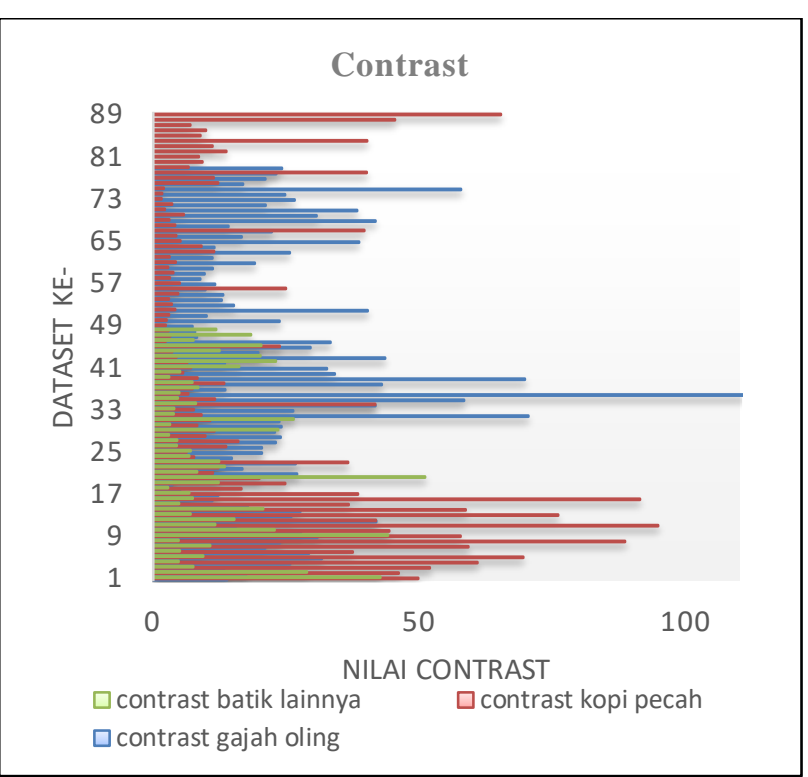

Gambar 3. Nilai kontras

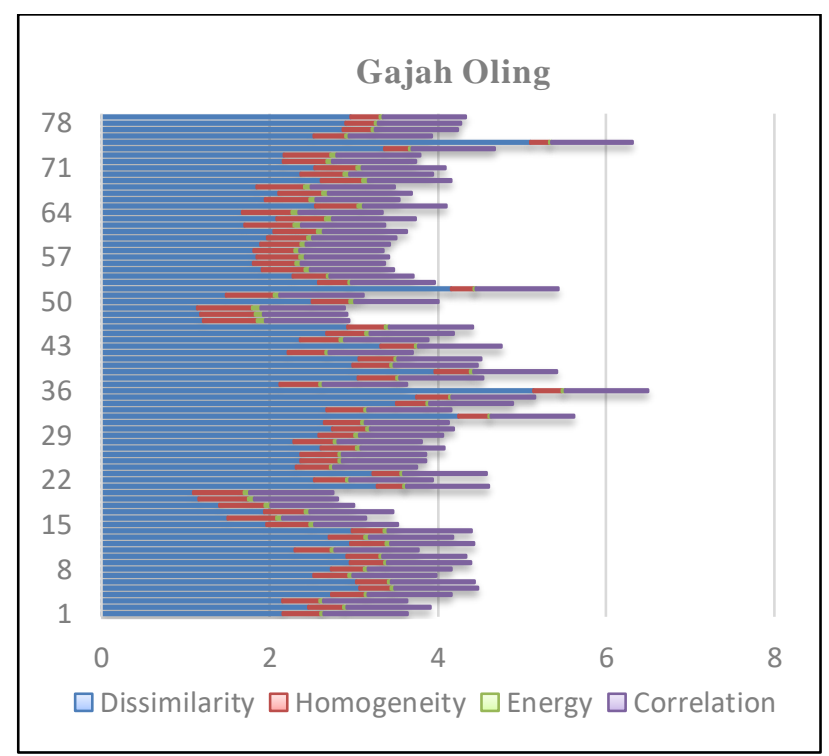

Gambar 4. Hasil ekstraksi fitur batik gajah oling

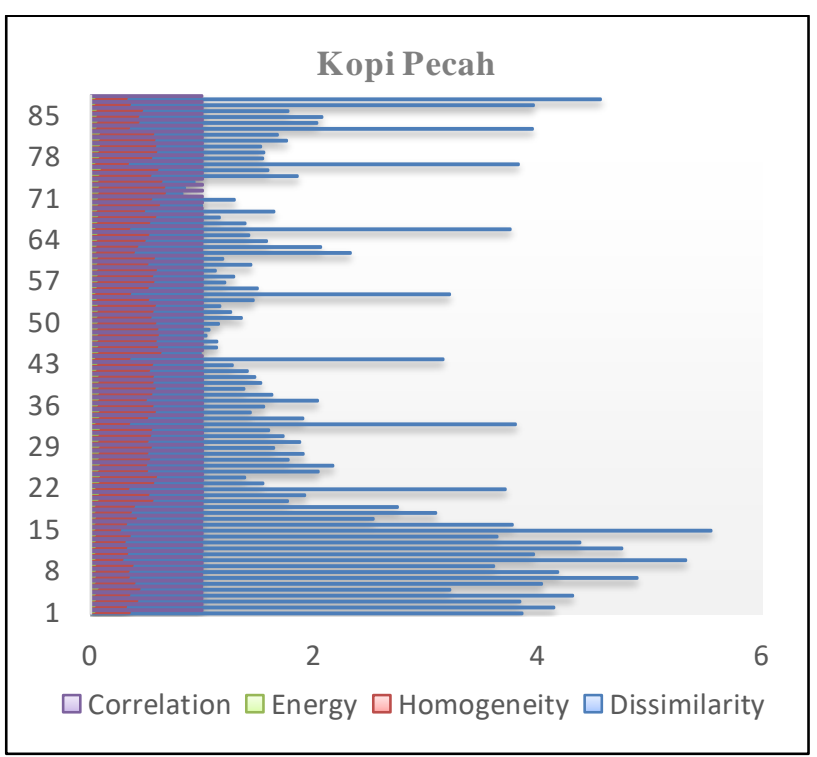

Gambar 5. Hasil ekstraksi fitur batik kopi pecah

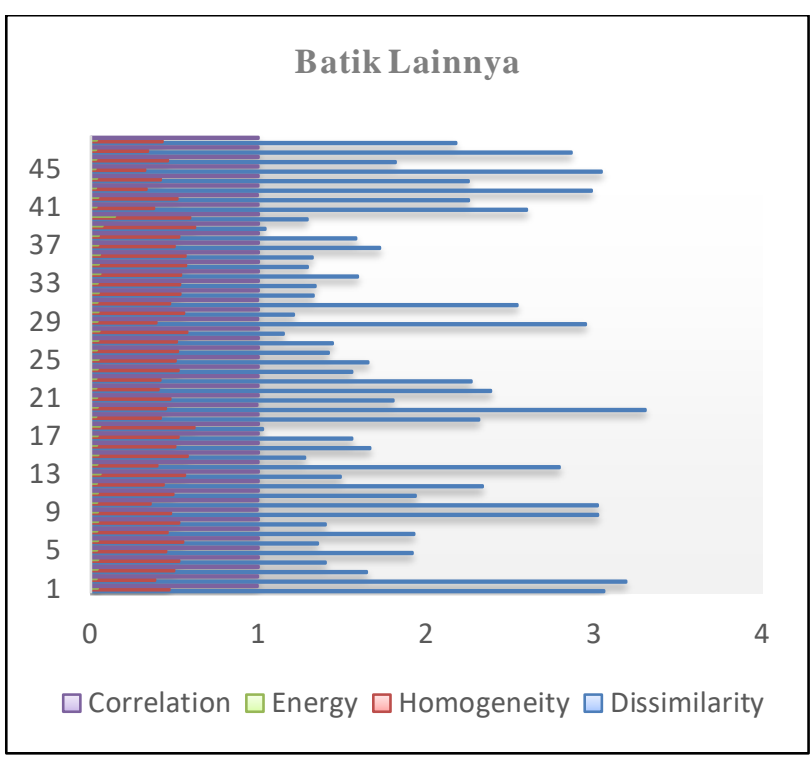

Gambar 6. Hasil ekstraksi fitur batik lainnya

Hasil ekstraksi fitur pada gambar di atas dibedakan berdasarkan kelasnya untuk fitur nilai korelasi, energi, homogenitas dan dissimilarity. Namun, pada hasil ekstraksi fitur dari nilai kontras dibedakan dengan fitur yang lain karena hasil yang didapatkan jauh lebih tinggi dibandingkan keempat fitur lainnya. Jika semua fitur dimasukkan dalam satu grafik, maka fluktuasi nilai grafik kurang bisa terbaca dengan baik. Untuk tahapan ini, pada penelitian ini menggunakan library scikit-image dan pandas yang merupakan library bahasa pemrograman python untuk keperluan analisis struktur data.

\subsection{Hasil Klasifikasi}

Tahap klasifikasi dimulai dengan tahap pelabelan terhadap data latih yang diperoleh dari hasil ekstraksi ciri dengan metode GLCM. Tujuan dari pelabelan ini adalah untuk mempermudah proses klasifikasi yakni pencocokan antara data tes dan data latih. Sehingga data tes dapat dideteksi termasuk batik gajah oling, kopi pecah atau bukan keduanya. Proses dari tahapan klasifikasi adalah melakukan rangkin selisih terendah diantara kelas yang ada. Jadi proses awal dari kNN adalah mencari nilai selisih dari semua data latih dan data tes. Setelah mendapatkan nilai selisih seluruhnya, kemudian dilakukan mapping untuk mencari nilai selisih terendah sebanyak sesuai dengan nilai parameter $K$. setelah ditemukan, maka dihitung nilai terendahnya lebih banyak di kelas yang mana dan jika dalam perangkingan diambil dalam voting terbanyak yang termasuk kelas yang terpilih.

Selanjutnya pada pengujian klasifikasi adalah menentukan nilai $\mathrm{K}$ terbaik. Nilai $\mathrm{K}$ yang diuji coba antara $\mathrm{K}=1$ sampai dengan $K=23$. Berdasarkan percobaan dari nilai $\mathrm{K}$ tersebut menunjukkan nilai akurasi tertinggi didapatkan pada $K=9$ dengan persentase akurasi sebesar 87,5\%. Persentase tersebut didapatkan dari proses uji dengan melibatkan 32 citra uji. Adapun akurasi dari hasil klasifikasi dari percobaan $\mathrm{K}=1$ sampai dengan $\mathrm{K}=23$ secara keseluruhan ditunjukkan pada gambar berikut. 


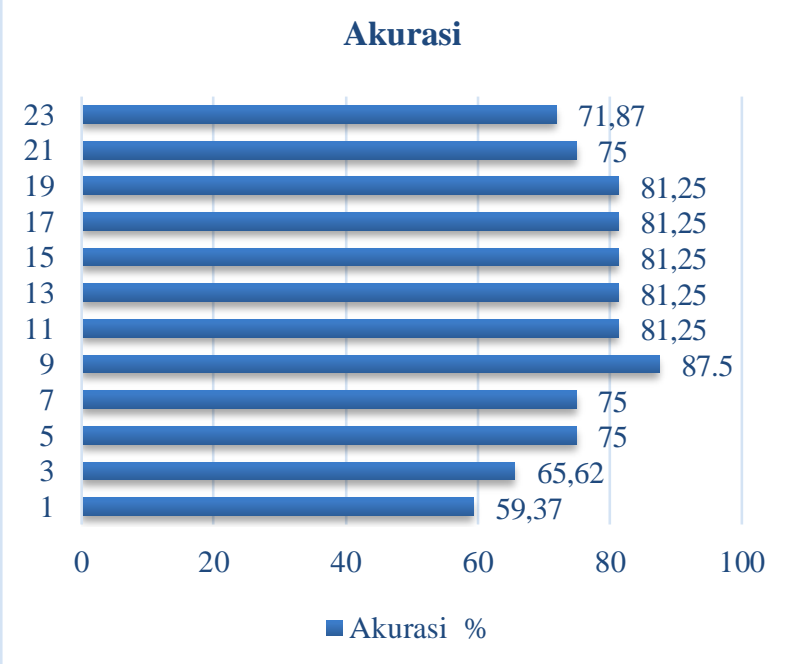

Gambar 7. Akurasi Hasil Deteksi atau Klasifikasi

Berdasarkan gambar diagram di atas menunjukkan bahwa nilai akurasi menunjukkan nilai yang konsisten pada nilai $K=9$ sampai dengan $K=19$. Sedangkan pada nilai $K$ lainnya masih menunjukkan nilai akurasi di bawah $80 \%$. Adapun sampel hasil deteksi ditunjukkan pada gambar berikut.
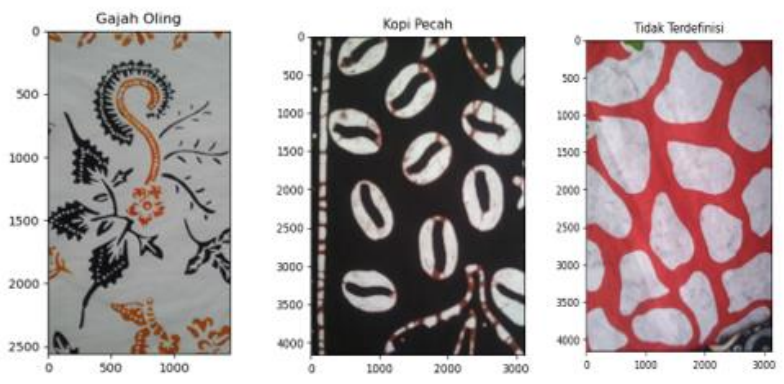

Gambar 8. Hasil Deteksi

Berdasarkan nilai akurasi yang didapatkan menunjukkan bahwa hasil deteksi masih terdapat beberapa kesalahan. Kesalahan tersebut diantaranya: 1) Beberapa dataset yang digunakan memiliki tekstur yang hampir sama dengan citra yang bukan di kelasnya, dan 2) Motif batik yang digunakan sebagai dataset memiliki bentuk atau teksutr yang hampir sama. Sehingga untuk batik selain kopi pecah dan gajah oling dipilih secara selektif karena beberapa batik memiliki nilai yang hampir sama dengan batik kopi pecah ataupun batik gajah oling.

\section{Kesimpulan}

Berdasarkan hasil eksperimen yang telah dilakukan didapatkan bahwa metode usulan yakni metode GLCM (Gray Level Co-occurrence matrics) dengan fitur kontras, dissimilarity, energy, homogenitas dan korelasi dapat bekerja dengan baik untuk kasus deteksi motif batik gajah oling, kopi pecah dan selain kedua motif batik tersebut. Dalam proses pembuatan sistem ini juga menggunakan metode kNN ( $k$-Nearest neighbors) sebagai metode klasifikasi yang dilakukan ujicoba dari $\mathrm{K}=1$ sampai dengan $\mathrm{K}=23$ yang didapatkan hasil akurasi optimasi dengan persentasel sebesar $87,5 \%$ dengan $\mathrm{K}=9$. Proses deteksi melibatkan sebanyak 216 citra data latih dan 32 citra sebagai data uji. Oleh karena itu, metode usulan pada penelitian ini bisa dijadikan pertimbangan dalam pengembangan sistem deteksi motif batik. Adapun dalam pengembangannya, sistem ini masih perlu banyak perbaikan seperti menambah dataset yang digunakan dan jenis motif batik yang dideteksi, karena di lapangan motif batik Banyuwangi ada banyak variannya yakni lebih dari 30 motif. Selain itu, dalam pengembangan sistem perlu pertimbangan pemilihan metode yang lebih relevan dengan jumlah dataset dan kelas yang banyak. Oleh karena itu, pada penelitian yang selanjutnya akan dilakukan pengembangan lebih lanjut dengan menggunakan metode deep learning dan juga melakukan penambahan dataset serta motif batik yang diklasifikasikan.

\section{Daftar Pustaka}

[1] I. Ratnawati, Batik Gajah Oling Banyuwangi. Malang: Pustaka Kaiswaran, 2011.

[2] I. M. A. Agastya and A. Setyanto, "Classification of Indonesian batik using deep learning techniques and data augmentation," Proc. - 2018 3rd Int. Conf. Inf. Technol. Inf. Syst. Electr. Eng. ICITISEE 2018, pp. 27-31, 2018, doi: 10.1109/ICITISEE.2018.8720990.

[3] C. U. Khasanah, E. Utami, and S. Raharjo, "Implementation of Data Augmentation Using Convolutional Neural Network for Batik Classification," 2020 8th Int. Conf. Cyber IT Serv. Manag. CITSM 2020, pp. 20-24, 2020, doi: 10.1109/CITSM50537.2020.9268890.

[4] T. Bariyah, M. A. Rasyidi, and N. Ngatini, "Convolutional Neural Network untuk Metode Klasifikasi Multi-Label pada Motif Batik," Techno.Com, vol. 20, no. 1, pp. 155-165, 2021, doi: $10.33633 /$ tc.v20i1.4224.

[5] D. Hardiyanto, S. Kristiyana, D. Kurniawan, and D. A. Sartika, "Klasifikasi Motif Citra Batik Yogyakarta Menggunakan Metode Adaptive Neuro Fuzzy Inference System," Setrum Sist. Kendali-Tenaga-elektronika-telekomunikasikomputer, vol. 8, no. 2, p. 229, 2019, doi: $10.36055 /$ setrum.v8i2.6545.

[6] A. S. Amal et al., "Motif dan Corak Batik Jawa Timur," Umm, pp. 1-12, 2014.

[7] B. S. V, A. Unnikrishnan, and K. Balakrishnan, "Grey Level Co-Occurrence Matrices: Generalisation and Some New Features," Int. J. Comput. Sci. Eng. Inf. Technol., vol. 2, no. 2, pp. 151-157, 2012, doi: 10.5121/ijcseit.2012.2213.

[8] Z. Zhang, "Introduction to machine learning: knearest neighbors," Ann. Transl. Med., vol. 4, no. 11, pp. 218-218, 2016, doi: 
10.21037/atm.2016.03.37.

[9] A. (Lovely P. U. Singh and B. Pandey, "An Euclidean Distance based kNN Computational Method for Assessing Degree of Liver Damage."

[10] D. J. Im and G. W. Taylor, "Learning a metric for class-conditional KNN," Int. Jt. Conf. Neural Networks, pp. 1932-1939, 2016, doi: 10.1109/IJCNN.2016.7727436.

[11] L. Hakim, A. D. Wibawa, E. Septiana Pane, and M. H. Purnomo, "Emotion Recognition in Elderly Based on $\mathrm{SpO} 2$ and Pulse Rate Signals Using Support Vector Machine," Proc. - 17th IEEE/ACIS Int. Conf. Comput. Inf. Sci. ICIS 2018, pp. 474-479, 2018, doi: 10.1109/ICIS.2018.8466489.

[12] L. Hakim, S. P. Kristanto, A. Z. Khoirunnisaa, and A. D. Wibawa, "Multi- scale Entropy and Multiclass Fisher 's Linear Discriminant for Emotion Recognition based on Multimodal Signal," Kinet. Game Technol. Inf. Syst. Comput. Network, Comput. Electron. Control, vol. 5, no. 1, pp. 71-78, 2020.

[13] C. Irawan, E. N. Ardyastiti, D. R. I. M. Setiadi, E. H. Rachmawanto, and C. A. Sari, "A survey: Effect of the number of GLCM features on classification accuracy of lasem batik images using K-nearest neighbor," 2018 Int. Semin. Res. Inf. Technol. Intell. Syst. ISRITI 2018, pp. 33-38, 2018, doi: 10.1109/ISRITI.2018.8864443.

[14] A. A. Kasim, R. Wardoyo, and A. Harjoko, "Batik classification with artificial neural network based ontexture-shape feature of main ornament," Int. J. Intell. Syst. Appl., vol. 9, no. 6, pp. 55-65, 2017, doi: $10.5815 /$ ijisa.2017.06.06.

[15] A. R. Juwita and A. Solichin, "Batik pattern identification using GLCM and artificial neural network backpropagation," Proc. 3rd Int. Conf. Informatics Comput. ICIC 2018, 2018, doi: 10.1109/IAC.2018.8780412.

[16] N. Yunari, E. M. Yuniarno, and M. H. Purnomo, "Indonesian batik image classification using statistical texture feature extraction Gray Level Co-occurrence Matrix (GLCM) and Learning Vector Quantization (LVQ)," J. Telecommun. Electron. Comput. Eng., vol. 10, no. 2-3, pp. 6771, 2018.

[17] R. A. Surya, "Ekstraksi Ciri Citra Batik Berdasarkan Tekstur Menggunakan Metode Gray Level Co Occurrence Matrix," Prosiding, 6 Desember 2016, Vol 2 No. 1, vol. 2, no. 1, pp. 146150, 2016, [Online]. Available: http://ars.ilkom.unsri.ac.id. 